\title{
Thermal ecotypes of amphi-Atlantic algae. I. Algae of Arctic to cold-temperate distribution (Chaetomorpha melagonium, Devaleraea ramentacea and Phycodrys rubens)
}

\author{
I. Novaczek, G. W. Lubbers \& A. M. Breeman \\ Department of Marine Biology, Biological Centre, University of Groningen; P.O. Box 14, \\ NL-9750 AA Haren $(G n)$, The Netherlands
}

\begin{abstract}
Three species of Arctic to cold-temperate amphi-Atlantic algae, all occurring also in the North Pacific, were tested for growth and/or survival at temperatures of -20 to $30^{\circ} \mathrm{C}$. When isolates from both western and eastern Atlantic shores were tested side-by-side, it was found that thermal ecotypes may occur in such Arctic algae. Chaetomorpha melagonium was the most eurythermal of the 3 species. Isolates of this alga were alike in temperature tolerance and growth rate but Icelandic plants were more sensitive to the lethal temperature of $25^{\circ} \mathrm{C}$ than were more southerly isolates from both east and west. With regard to Devaleraea ramentacea, one Canadian isolate grew extraordinarily well at -2 and $0^{\circ} \mathrm{C}$, and all tolerated temperatures $2-3^{\circ} \mathrm{C}$ higher than the lethal limit $\left(18-20^{\circ} \mathrm{C}\right)$ of isolates from Europe. Concerning Phycodrys rubens, both eastern and western isolates died at $20^{\circ} \mathrm{C}$ but European plants tolerated the lethal high temperature longer, were more sensitive to freezing, and attained more rapid growth at optimal temperatures. The intertidal species, $C$. melagonium and D. ramentacea, both survived freezing at -5 and $-20^{\circ} \mathrm{C}$, at least for short time periods. $C$. melagonium was more susceptible than $D$. ramentacea to desiccation. Patterns of thermal tolerance may provide insight into the evolutionary history of seaweed species.
\end{abstract}

\section{INTRODUCTION}

Algal species of the North Atlantic Ocean may have had diverse evolutionary origins (Lüning, 1985). Some 165 my ago, the developing ocean basin opened into the tropical Tethys Sea, and algae presumably migrated from there (Smith et al., 1981). After North America separated from South America roughly $140 \mathrm{my}$ ago (Lamb, 1977), and thereafter up until 3-5 my ago (Briggs, 1987), algae could also have entered from the eastern Pacific.

Other algae could have reached the Atlantic from the north. The present Arctic Sea, originally an arm of the Pacific (Smith et al., 1981), was cut off from the North Pacific by Beringia. Initially linked to the Tethys and Pacific Oceans by shallow epicontinental seas, it later may have been virtually landlocked for several million years. Between 40 and 55 my BP (Frakes, 1979), Greenland and Norway separated, allowing the temperate waters and, possibly, a distinct cool-water flora of the polar sea to enter the tropical North Atlantic. During the subsequent period of global cooling (Thunell \& Belyea, 1982), there may have been a burst of speciation and extinction as northern populations of Tethyan 
and Arctic algae either adapted or perished under the stress (van den Hoek, 1984; Lüning, 1985).

Species from the North Pacific Ocean could also have migrated into the Arctic and North Atlantic after the disruption of the Bering land bridge perhaps 2-3 my ago. Evidence of interoceanic migration of molluscs at this time has been found in fossil deposits (McKenna, 1983).

Over the past 2.5-3 my, recurring glaciations may have caused extinctions on one or both sides of the ocean (van den Hoek, 1984; Lüning, 1985; van den Hoek \& Breeman, 1990). Ice fields also separated algal populations occupying eastern and western sides of the Atlantic. For many pan-Arctic species, effective isolation may have occurred only during glaciations. For Arctic and temperate species with poor dispersive ability, populations may have been separated earlier (prior to $10 \mathrm{my}$ BP) by the sinking of the Greenland-Scotland ridge (Thiede \& Endholm, 1983). Warm temperate and tropical taxa could have been split up by the initial cooling of the north Atlantic or they may have had sporadic genetic exchange across the northern islands up until the most recent warm period around 20 my BP (Frakes, 1979).

Not only have populations of amphi-Atlantic species been separated to various degrees and for various lengths of time but they have also been subject to different temperature regimes owing to patterns of circulation and upwelling (Breeman, 1988, 1990). The more dramatic thermal fluctuations of the western shores may date back to the development of the Labrador Current system, 3 my BP (Berggren \& Hollister, 1977). During glacial periods, however, seasonality was reduced on this coast (CLIMAP-Project Members, 1981). Evidence of upwelling in the eastern Atlantic during the last glaciation has been found (Thiede, 1979; CLIMAP-project members, 1981) and there is no reason to doubt that this process has moderated summer temperatures in the region for a longer time period.

Given the genetic isolation and differing environments of many amphi-Atlantic algal populations, one might expect to find that they have diverged in terms of thermal response. A further hypothesis is that ecotypic variation might be more common in species that have totally disjunct distributions, as opposed to pan-Arctic species that have some possibility of genetic interchange. Furthermore, among those species having a southerly distribution, ecotypic variation might be most prevalent in those that have been in the Atlantic Ocean for the longest time, i.e. those of Tethyan origin.

To determine to what extent ecotypic variation in thermal response occurs in amphiAtlantic species, we have brought into culture isolates of species of various distributional types from both sides of the ocean and tested them side-by-side for the ability to survive and grow in different temperatures. In this paper we report on three pan-Arctic species, Chaetomorpha melagonium (Web. et Mohr) Kütz., Devaleraea ramentacea (L.) Guiry and Phycodrys rubens (L.) Batt.

\section{MATERIALS AND METHODS}

Isolates of all 3 species were collected from both eastern and western shores of the North Atlantic Ocean (Table 1). Unialgal clones of all isolates were propagated from vegetative tissue or occasionally from spores (see Table 1) at $5^{\circ}$ and/or $10^{\circ} \mathrm{C}$, in long $(16 \mathrm{~h})$ days. To test for growth and survival, each isolate was incubated in growth 
Table 1. Place and year of collection of algal isolates. $(t)=$ tetrasporophyte, $(m)=$ male, $(f)=$ female

\begin{tabular}{|cll|}
\hline Species/Code & Location & Year \\
\hline $\begin{array}{c}\text { Chaetomorpha melagonium } \\
\text { CMASS }\end{array}$ & Woods Hole, Mass., USA & 1971 \\
CBRIT & Roscoff, Brittany, France & 1986 \\
CHELG & Helgoland, FRG & 1987 \\
CICE1 & Iceland & 1987 \\
CICE2 & Iceland & 1987 \\
Devaleraea ramentacea & & \\
DCAN1 (t) & NW Cove, N.S., Canada & 1986 \\
DCAN2 $(\mathrm{t})$ & Peggys Cove, N.S., Canada & 1986 \\
DCAN2 (m) & Peggys Cove, N.S., Canada (from tetraspores) & 1986 \\
DCAN3 (t) & Peggys Cove, N.S., Canada & 1986 \\
DJM $(\mathrm{m})$ & Jan Mayen Is. & 1978 \\
DNOR1 & Tromsø, Norway & 1982 \\
DNOR2 & Tromsø, Norway & 1987 \\
DICE $\quad(\mathrm{t})$ & Iceland & 1987 \\
Phycodrys rubens & & 1986 \\
PCAN1 & Wolf Is., Bay of Fundy, & 1986 \\
PCAN2 & N.B., Canada (from tetraspores) & 1987 \\
PEUR1 & Anglo, P.E.I., Canada & 1987 \\
PEUR2 & Plougarneau, Brittany, France & 1987 \\
PEUR3 & Plougarneau, Brittany, France & \\
\hline
\end{tabular}

chambers $\left( \pm 1-2^{\circ} \mathrm{C}\right)$ at temperatures ranging from 5 to $30^{\circ} \mathrm{C}$ and in water baths $( \pm$ $0.5^{\circ} \mathrm{C}$ ) at temperatures of 0 and $-2{ }^{\circ} \mathrm{C}$ (i.e. $-1.8^{\circ} \mathrm{C}$ in unfrozen seawater at $33 \%$ ). All cultures received cool white fluorescent light of 10,20 or $40 \mu \mathrm{mol} \mathrm{m}^{-2} \mathrm{~s}^{-1}$. Sterile PES medium (McLachlan, 1973) was made from $33 \%$ salinity, North Sea water.

Prior to either growth or survival trials, all material was moved from the stock condition towards the experimental temperature in stages of no more than $5^{\circ} \mathrm{C} \mathrm{wk}^{-1}$, and then trimmed and acclimated at the experimental temperature for at least 5 days before growth trials began. All isolates of any one species were tested concurrently.

For each growth trial, 5 healthy plants (Chaetomorpha melagonium) or plant segments (other species) from each clone were incubated separately in sterile plastic Petri dishes $(10 \mathrm{~cm} \varnothing)$ containing $50 \mathrm{ml}$ of medium and sealed with parafilm. For trials conducted in water baths, the plant material was incubated in test tubes containing $20 \mathrm{ml}$ of medium. Whole juvenile plants of Chaetomorpha melagonium, all generated from spores in culture and at least $2 \mathrm{~mm}$ in length, were used for growth trials. In the case of Devaleraea ramentacea, apices 5-10 mm long were used and in the case of Phycodrys rubens, small leaflets were employed. For each species, the average initial size of experimental subjects was similar in all trials. Using a camera lucida on a dissecting microscope, the lengths of the former two species and the surface area of the latter (after flattening under a glass cover slip) were traced at $7 \times$ magnification. The tracings were later measured using a computer digitiser to give the length or, in the case of $P$. rubens, the surface area. Measurements were made at intervals of 2 to 10 days, depending upon the rate of growth, until a straight line on semi-log paper, indicating steady logarithmic 
increase, could be drawn between at least three consecutive data points. The relative growth rate (Kain, 1987), expressed as $\%$ increase $d^{-1}$, was computed for the period of exponential growth. Experiments were conducted at 10 and/or $40 \mu \mathrm{mol} \mathrm{m} \mathrm{m}^{-2} \mathrm{~s}^{-1}$ at temperatures of $-2,0,5,10,15,18,20,22$, and $25^{\circ} \mathrm{C}$. Separate growth trials on $C$. melagonium were conducted as above, using $1-\mathrm{cm}$ fragments of young plants incubated in test tubes. In this case, the increase in cell numbers was monitored.

Differences among isolates were tested using a posteriori Student-Neuman-Keuls (SNK) and Scheffe multiple range tests, using subprogram "oneway" from the Statistical Package for the Social Sciences (SPSS).

To determine lethal limits, whole plants (including holdfasts) were incubated in 500-ml flasks at extreme temperatures for a period of 3 months, to simulate a winter or summer time span. The medium was changed every 2-3 weeks, after being warmed or cooled to the experimental temperature so as to avoid thermal shocks. Temperatures of $-2,0,18,20,23,25,27$ and $30^{\circ} \mathrm{C}$ were tested. A photon fluence rate of $10 \mu \mathrm{mol} \mathrm{m}^{-2} \mathrm{~s}^{-1}$ was used because of the tendency of algae to be sensitive to light at sublethal temperatures. At $0^{\circ} \mathrm{C}$, incubations were also performed in total darkness. In the case of Chaetomorpha melagonium, both juvenile and full-sized adult plants were tested for thermal tolerance. At the end of the test period, plants were returned to stock culture conditions and monitored for up to 3 months for signs of regrowth. Trials were repeated on at least 2 separate occasions.

Response to high temperatures was also investigated by two other procedures for Chaetomorpha melagonium and Devaleraea ramentacea. Firstly, growth rates over 6-8 weeks were monitored at sub-lethal high temperatures. Secondly, to test for short-term lethal effects, plant apices, each in a test tube of medium, were incubated in a cryostat $\left( \pm 0.5^{\circ} \mathrm{C}\right)$ for a two-wk period. Tests were performed on 10 replicates at each of the following temperatures: $16,18,20,22,24,26,28$ and $30^{\circ} \mathrm{C}$. Following the test period, plant material was returned to $10^{\circ} \mathrm{C}$ and monitored for regrowth.

Resistances to freezing and/or desiccation were also tested. Plant segments were taken from long-term culture at $5^{\circ} \mathrm{C}$ and held at $0^{\circ} \mathrm{C}$ for at least 1 week before being incubated in the dark at -5 and $-20^{\circ} \mathrm{C}$, either in ice or in air. Tissues were cooled to $-5^{\circ} \mathrm{C}$ at a rate of $1.1^{\circ} \mathrm{C} \mathrm{min}^{-1}$ and to $-20^{\circ} \mathrm{C}$ at a rate of $2.3^{\circ} \mathrm{C} \mathrm{min}^{-1}$. For some tests, plants were pre-dried to various extents at $4{ }^{\circ} \mathrm{C}_{i}$ otherwise all tissues were fully hydrated. After test periods ranging from 1 hour to 14 days, the plant material was thawed in seawater at $0^{\circ} \mathrm{C}$ and then transferred to 5 or $10^{\circ} \mathrm{C}$ and monitored for regrowth.

\section{RESULTS}

\section{Chaetomorpha melagonium}

G rowth. The two growth experiments, in which either length (Fig. 1a-c) or cell number (Fig. 1d-i) of isolates CMASS, CBRIT and CHELG were measured, gave similar results. When lengths were measured, CBRIT had significantly higher rates of elongation than the other isolates at $5-15^{\circ} \mathrm{C}$ but no such differences were apparent in the trial in which cells were counted. All isolates grew slowly at -2 and $0^{\circ} \mathrm{C}$, in both long days (Fig. $1 \mathrm{a}-\mathrm{f}$ ) and short days (Fig. $1 \mathrm{~g}-\mathrm{i}$ ). Maximum rates of growth generally occurred at $10-15^{\circ} \mathrm{C}$, although growth at the sublethal temperature of $22^{\circ} \mathrm{C}$ could be rapid for a short period of 

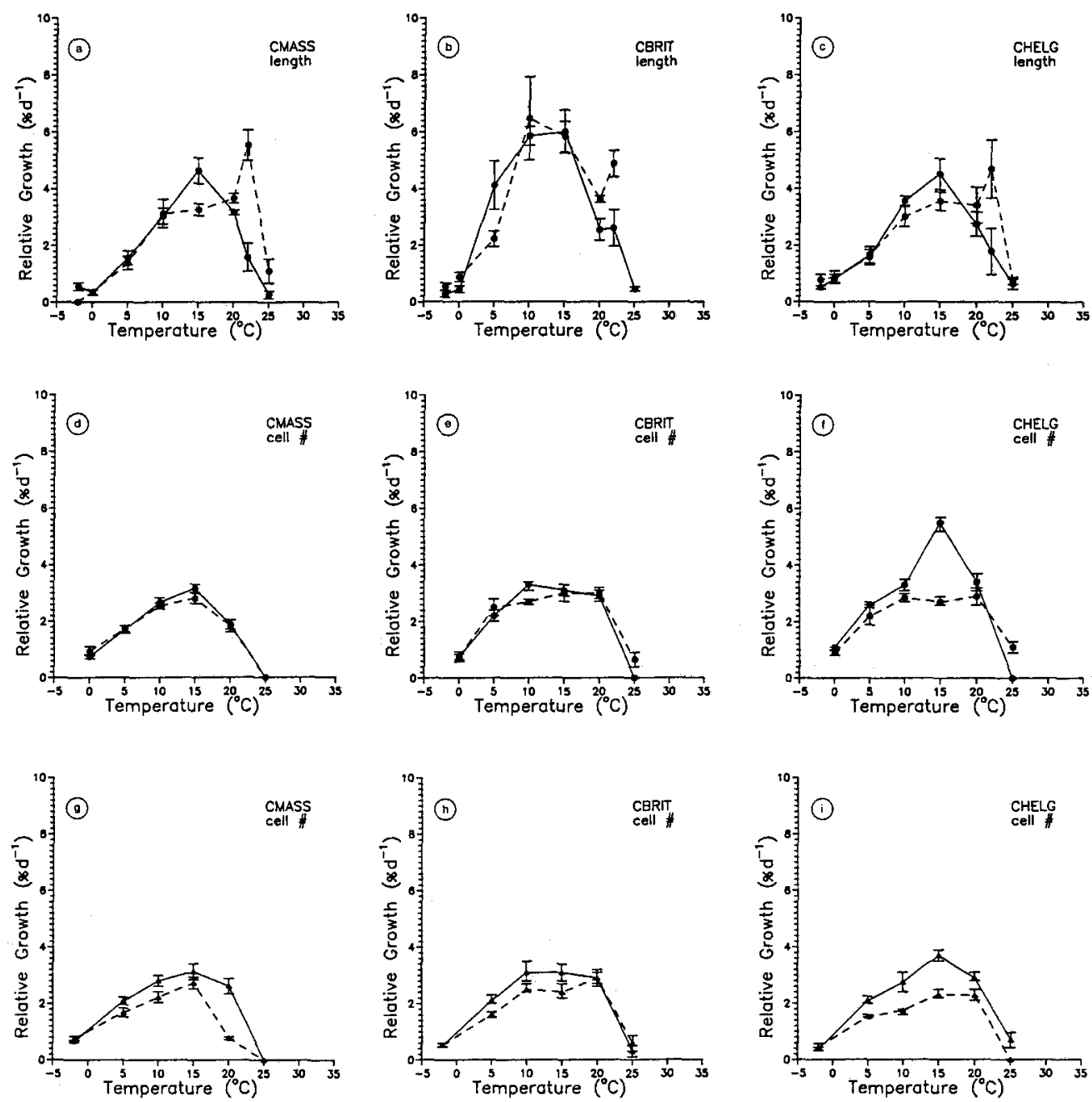

Fig. 1. Relative growth rates (mean \pm standard error) of isolates of Chaetomorpha melagonium at various temperatures and at photon fluence rates of $10 \mu \mathrm{mol} \mathrm{m} \mathrm{m}^{-2} \mathrm{~s}^{-1}$ (dashed line) and $40 \mu \mathrm{mol} \mathrm{m} \mathrm{m}^{-2}$ $\mathrm{s}^{-1}$ (solid line). a-c Increase in filament length in 16-h days. $d-f$ Increase in cell number in 16-h days. $\mathrm{g}$-i Increase in cell number in 8-h days. Isolate indicated in upper right hand corner of each graph

time. When monitored over weeks, it was found that growth rates at $22^{\circ} \mathrm{C}$ declined steadily, stabilizing near zero after 3-4 weeks (Fig. 2). At $25^{\circ} \mathrm{C}$, growth approached zero within the 5-day acclimation period. In most cases there was no significant difference between growth rates at high and low photon fluence rates. With the exception of CHELG at $15^{\circ} \mathrm{C}$, rates of cell division were also comparable in long-versus short-day conditions.

High-temperature tolerance. When tested for 2-wk periods at high temperatures, juvenile plants of isolates CMASS, CBRIT and CHELG survived at tem- 

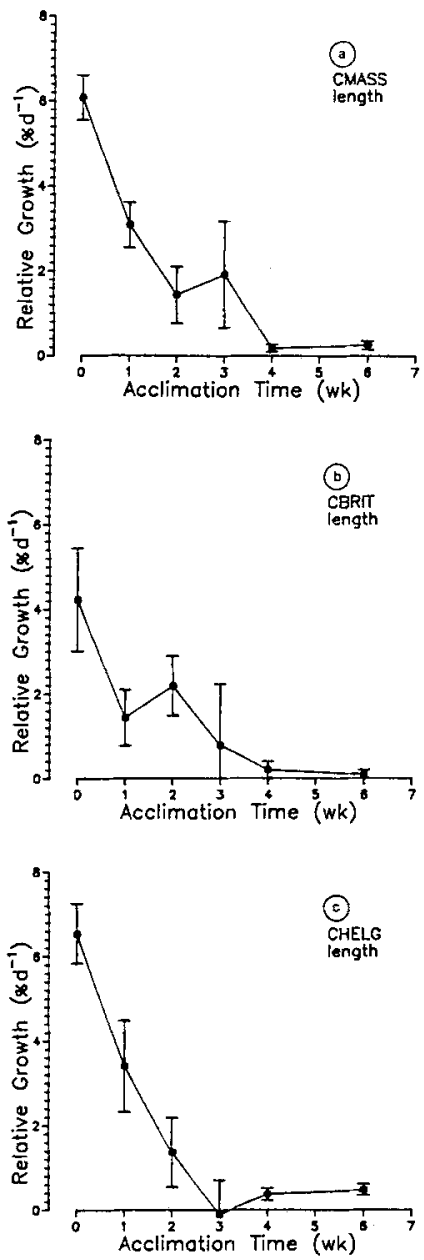

Fig. 2. Decline in relative growth rates (mean \pm standard error) of isolates of Chaetomorpha melagonium over time at $22^{\circ} \mathrm{C}$ in 16 -h days. Isolate indicated in upper right hand corner of each graph

peratures up to and including $26^{\circ} \mathrm{C}$, but all died at $28^{\circ} \mathrm{C}$ (Table 2). In trials lasting 3 months, however, both juvenile and mature plants of the above isolates and of isolates CICE1 and CICE2, were damaged or died at 23 and $25^{\circ} \mathrm{C}$, and died after $2-6$ weeks at 27 and $30^{\circ} \mathrm{C}$ (Table 3). Only the Icelandic isolates (CICE1 and CICE2) consistently died at $25^{\circ} \mathrm{C}$ a few replicates of all 3 more southerly isolates survived this temperature (with damage). Mature plants tended to persist longer at high lethal temperatures than did the juveniles, and the smaller juveniles were the most sensitive.

Low-temperature tolerance. All isolates survived 3 months at 0 and $-2{ }^{\circ} \mathrm{C}$, even in total darkness (Table 3). The isolates CMASS, CBRIT and CHELG were compared for resistance to desiccation and freezing (Table 4). In all cases, drying out to $70-80 \%$ of initial fresh weight at $4{ }^{\circ} \mathrm{C}$ was in itself lethal. Plants could, however, survive 
Table 2. Survival of fragments or apices, respectively, of Chaetomorpha melagonium and Devaleraea ramentacea after incubation for 2 weeks at temperatures of 16 to $30^{\circ} \mathrm{C}$ in long days $(16 \mathrm{~h})$ at $20 \mu \mathrm{mol} \mathrm{m} \mathrm{m}^{-2} \mathrm{~s}^{-1}$. In each case $\mathrm{n}=10$

\begin{tabular}{|c|c|c|c|c|c|c|c|c|}
\hline & \multicolumn{8}{|c|}{$\%$ Survival at each temperature $\left({ }^{\circ} \mathrm{C}\right)$} \\
\hline & 16 & 18 & 20 & 22 & $2 \overrightarrow{4}$ & 26 & 28 & 30 \\
\hline \multicolumn{9}{|l|}{ C. melagonium } \\
\hline CMASS & 100 & 100 & 100 & 100 & 100 & 80 & 0 & 0 \\
\hline CBRIT & 100 & 100 & 100 & 100 & 100 & 100 & 0 & 0 \\
\hline CHELG & 100 & 100 & 100 & 100 & 100 & 100 & 0 & 0 \\
\hline \multicolumn{9}{|l|}{ D. ramentacea } \\
\hline DCAN1 & 100 & 100 & 100 & 90 & 0 & 0 & 0 & 0 \\
\hline DCAN2 (t) & 100 & 100 & 100 & 80 & 0 & 0 & 0 & 0 \\
\hline DCAN3 & 100 & 100 & 100 & 80 & 0 & 0 & 0 & 0 \\
\hline DNOR1 & 100 & 100 & 50 & 50 & 0 & 0 & 0 & 0 \\
\hline DNOR2 & 100 & 100 & 30 & 10 & 0 & 0 & 0 & 0 \\
\hline DJM & 100 & 100 & 60 & 0 & 0 & 0 & 0 & 0 \\
\hline DICE & 100 & 100 & 20 & 20 & 0 & 0 & 0 & 0 \\
\hline
\end{tabular}

Table 3. Thermal tolerance of whole plants of Chaetomorpha melagonium in trials of 3 months duration. $L=$ long days $(16 \mathrm{~h}), \mathrm{S}=$ short days $(8 \mathrm{~h}), \mathrm{D}=$ dark $_{\mathrm{i}}++=$ undamaged, + damaged but recovered, $+-=$ damaged or dead in repeated trials, $-=\operatorname{dead}_{i}$ ju $=$ juvenile plants, ad $=$ adult plants, nd = no data

\begin{tabular}{|c|c|c|c|c|c|c|c|c|c|c|c|c|c|}
\hline \multirow[t]{3}{*}{ Isolate } & \multicolumn{13}{|c|}{ Temperature $\left({ }^{\circ} \mathrm{C}\right)$ and Daylength } \\
\hline & $-2 S$ & OL & $\mathrm{OD}$ & \multicolumn{2}{|c|}{$20 \mathrm{~L}$} & \multicolumn{2}{|c|}{$23 \mathrm{~L}$} & \multicolumn{2}{|c|}{$25 \mathrm{~L}$} & \multicolumn{2}{|c|}{$27 \mathrm{~L}$} & \multicolumn{2}{|c|}{$30 \mathrm{~L}$} \\
\hline & $\mathrm{ad}$ & ad & ad & ju & ad & ju & ad & ju & ad & ju & ad & ju & ad \\
\hline CMASS & ++ & ++ & ++ & ++ & ++ & - & +- & +- & +- & - & - & - & - \\
\hline CBRIT & ++ & ++ & ++ & nd & ++ & nd & +- & +- & - & - & - & - & - \\
\hline CHELG & ++ & ++ & ++ & nd & ++ & +- & + & +- & +- & - & - & - & - \\
\hline CICE1 & ++ & ++ & ++ & ++ & ++ & - & +- & - & - & - & - & - & nd \\
\hline CICE2 & $+t$ & ++ & ++ & $+t$ & ++ & - & +- & - & - & - & - & - & nd \\
\hline
\end{tabular}

for a week after being quickly frozen in air or in water at $-5^{\circ} \mathrm{C}$. Survivorship, after being frozen in water at $-20^{\circ} \mathrm{C}$, was good after 1 hour but declined to zero within 24 hours. If frozen to $-20^{\circ} \mathrm{C}$ in air, some replicates of all isolates survived for 4 or 24 hours. No plant survived a week at $-20^{\circ} \mathrm{C}$ in any condition.

\section{Devaleraea ramentacea}

Growth. In an analysis of variance of growth rates of Devaleraea ramentacea, temperature, photon fluence rate and isolate were all highly significant factors $(\mathrm{P}<0.001)$. Significantly higher rates of growth were recorded in long days than in short days at $0^{\circ} \mathrm{C}$ (Fig. 3). Canadian isolates had growth optima at 0 or $5^{\circ} \mathrm{C} \mathrm{(Fig.} \mathrm{3),} \mathrm{and} \mathrm{at} \mathrm{least}$ one of these isolates grew significantly faster than all European plants at -2 and $0^{\circ} \mathrm{C}$. In European plants, maximum growth occurred at 5 or $10^{\circ} \mathrm{C}$. In long-day conditions, an enhancement of growth in higher photon fluence rates was often statistically significant 
Table 4. Survival of fragments of Chaetomorpha melagonium after different periods of time at -5 and $-20^{\circ} \mathrm{C}$, either immersed in water (W) or in air (D). nd = no data

\begin{tabular}{|c|c|c|c|c|}
\hline \multirow[t]{2}{*}{ Isolate } & \multirow[t]{2}{*}{ W/D } & \multirow[t]{2}{*}{ Time } & \multicolumn{2}{|c|}{$\%$ Survival $(n=4-8)$} \\
\hline & & & $-5^{\circ} \mathrm{C}$ & $-20^{\circ} \mathrm{C}$ \\
\hline \multirow[t]{7}{*}{ CMASS } & D & $4 \mathrm{~h}$ & 75 & 0 \\
\hline & & $1 \mathrm{~d}$ & 100 & 12 \\
\hline & & $7 \mathrm{~d}$ & 100 & 0 \\
\hline & W & $1 \mathrm{~h}$ & nd & 100 \\
\hline & & $4 \mathrm{~h}$ & 100 & 0 \\
\hline & & $1 \mathrm{~d}$ & 100 & 0 \\
\hline & & $7 \mathrm{~d}$ & 100 & 0 \\
\hline \multirow{7}{*}{ CBRIT } & D & $4 \mathrm{~h}$ & 100 & 12 \\
\hline & & $1 \mathrm{~d}$ & nd & 25 \\
\hline & & $7 \mathrm{~d}$ & 100 & 0 \\
\hline & W & $1 \mathrm{~h}$ & nd & 100 \\
\hline & & $4 \mathrm{~h}$ & 50 & 0 \\
\hline & & $1 \mathrm{~d}$ & 100 & 0 \\
\hline & & $7 d$ & 88 & 0 \\
\hline \multirow[t]{7}{*}{ CHELG } & $\mathrm{D}$ & $4 \mathrm{~h}$ & 100 & 25 \\
\hline & & $1 \mathrm{~d}$ & nd & 0 \\
\hline & & $7 d$ & 100 & 0 \\
\hline & W & $1 \mathrm{~h}$ & nd & 75 \\
\hline & & $4 \mathrm{~h}$ & 100 & 12 \\
\hline & & $1 \mathrm{~d}$ & 100 & 0 \\
\hline & & $7 \mathrm{~d}$ & 78 & 0 \\
\hline
\end{tabular}

in Canadian plants but was rarely observed in European plants. For DCAN2, growth varied significantly with temperature and photon fluence rate but not with phase (tetrasporophyte versus male) or daylength. In most cases, growth rates dropped dramatically at $15^{\circ} \mathrm{C}$, and long-term monitoring revealed that at both 15 and $18^{\circ} \mathrm{C}$, growth rates declined to zero within 2-6 weeks (Fig. 4). DCAN3 was particularly tolerant of high temperatures. It had a significantly higher rate of growth than all others after 1 week at $18^{\circ} \mathrm{C}$ and was still growing after 6 weeks at this temperature.

$\mathrm{High-temperature} \mathrm{tolerance.} \mathrm{Isolates} \mathrm{from} \mathrm{the} \mathrm{eastern} \mathrm{and} \mathrm{western}$ Atlantic differed consistently in their upper tolerance limits. In short-term tests (Table 2), at least $80 \%$ of replicates of Canadian isolates tolerated $22^{\circ} \mathrm{C}$ for 2 weeks, while no more than $50 \%$ of European plants tolerated this treatment. Even at $20^{\circ} \mathrm{C}$, all the European clones suffered some mortality after 2 weeks. In 3-month trials (Table 5), it was found that the upper lethal limit for the European isolates lay between 18 and $20^{\circ} \mathrm{C}$, whereas Canadian isolates survived with damage at $20^{\circ} \mathrm{C}$ and died at $23^{\circ} \mathrm{C}$.

Low-temperature tolerance. Both European and Canadian plants remained healthy at 0 and $-2{ }^{\circ} \mathrm{C}$ in light and at $0^{\circ} \mathrm{C}$ in darkness for 3 months (Table 5). All isolates were damaged but survived after being dried to as little as $60 \%$ of original fresh weight at $4^{\circ} \mathrm{C}$. Survival was good when plants were frozen in water or in air for up to a week at $-5^{\circ} \mathrm{C}$, but they died if first dried at $4^{\circ} \mathrm{C}$ (Table 6). Survivorship declined with time in material frozen to $-20^{\circ} \mathrm{C}$, especially if frozen in air. Contrary to the trend at $-5^{\circ} \mathrm{C}$, long-term survivorship in air at $-20^{\circ} \mathrm{C}$ was better after pre-drying at $4{ }^{\circ} \mathrm{C}$. 

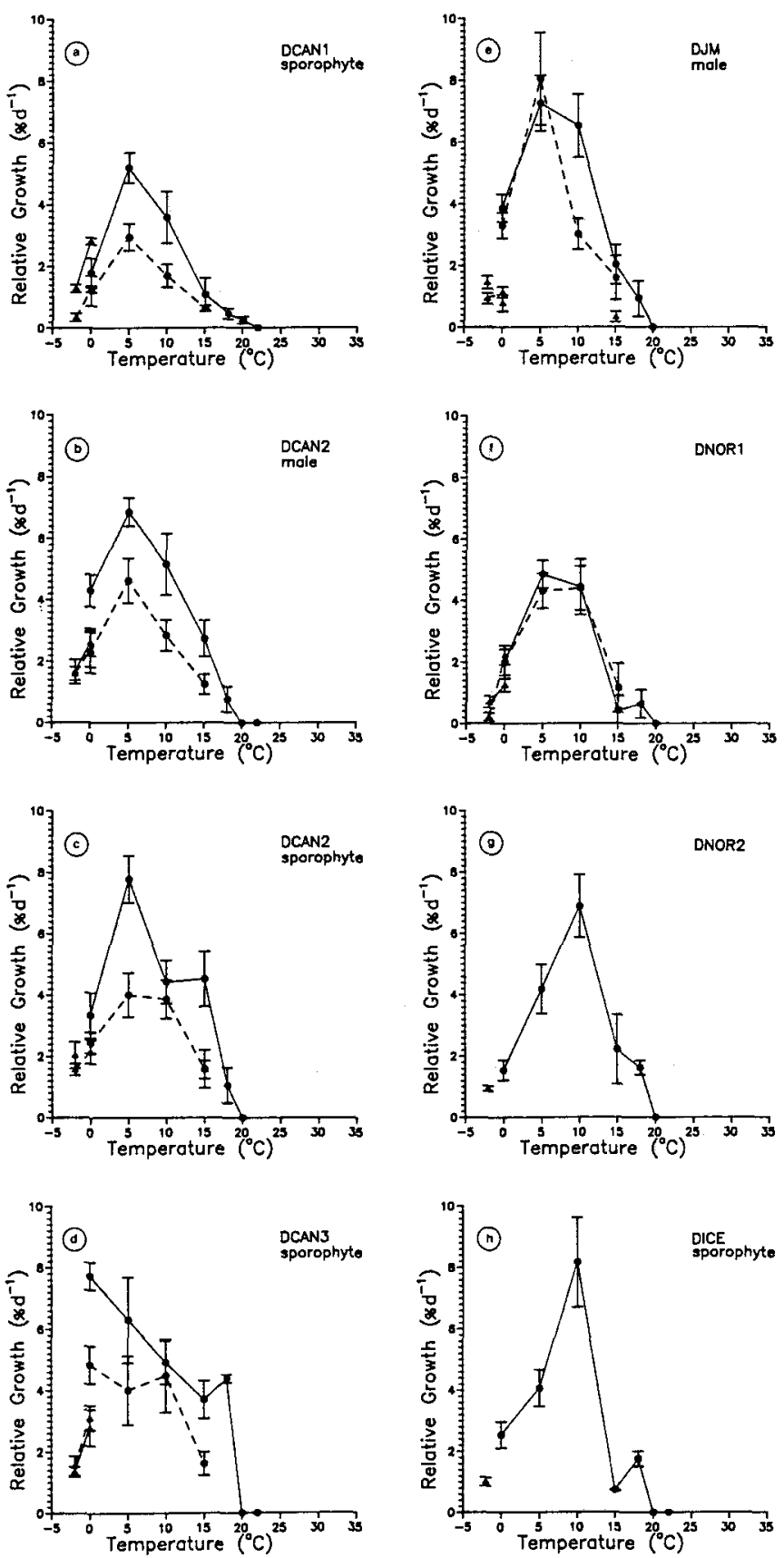

Fig. 3. Relative growth rates (mean \pm standard error) of isolates of Devaleraea ramentacea at various temperatures at photon fluence rates of $10 \mu \mathrm{mol} \mathrm{m}{ }^{-2} \mathrm{~s}^{-1}$ (dashed line) and/or $40 \mu \mathrm{mol} \mathrm{m}^{-2} \mathrm{~s}^{-1}$ (solid line) in 8-h days (triangles) or 16-h days (circles). Isolate indicated in upper right hand corner of each graph. a-d Canadian isolates. e-h European isolates 

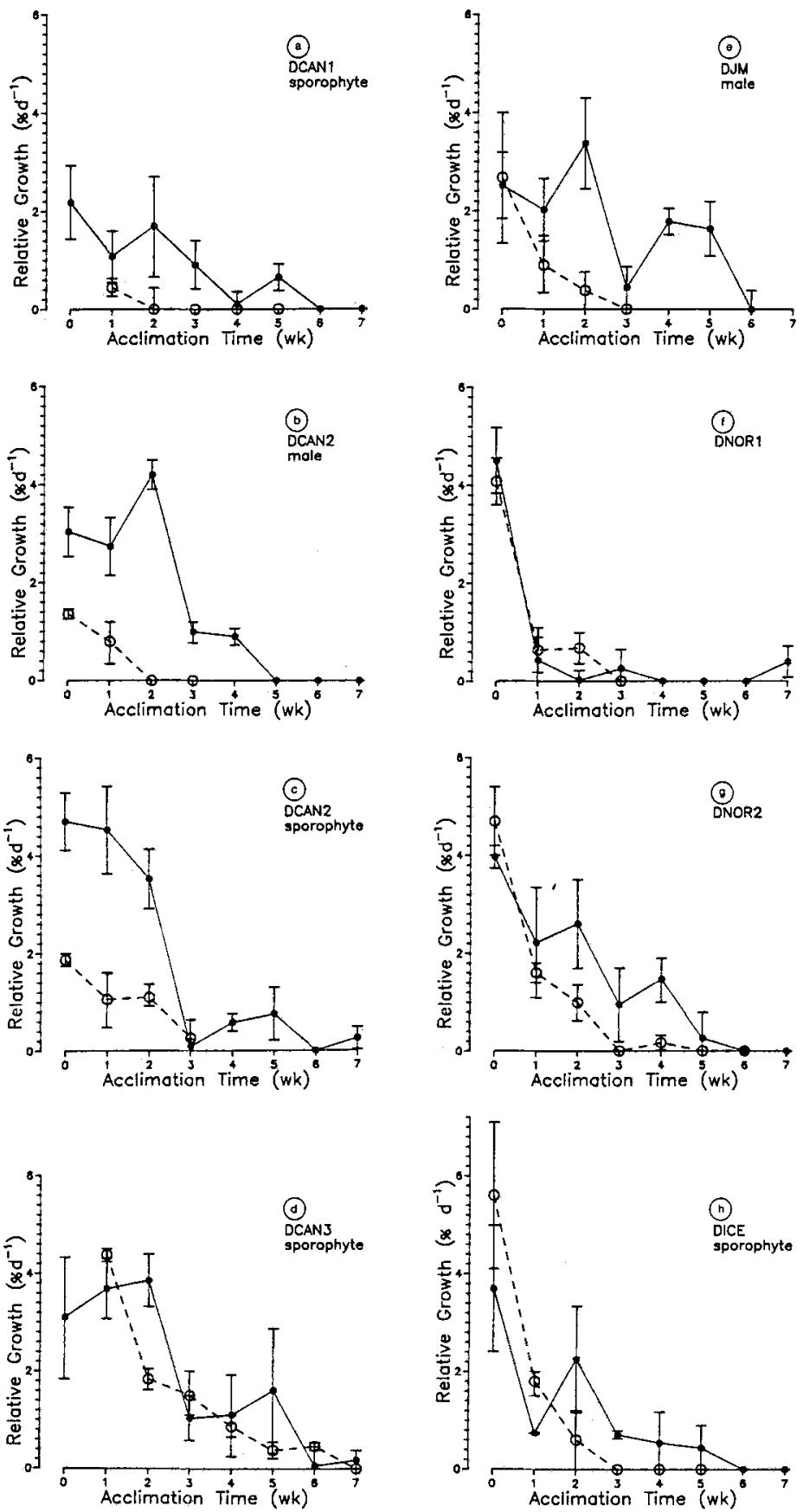

Fig. 4. Decline of relative growth rates (mean \pm standard error) of isolates of Devaleraea ramentacea over time at $15^{\circ} \mathrm{C}$ (solid line) and $18^{\circ} \mathrm{C}$ (dashed line) in 16 -h days at $40 \mu \mathrm{mol} \mathrm{m} \mathrm{m}^{-2} \mathrm{~s}^{-1}$.. Isolate indicated in upper right hand corner of each graph. a-d Canadian isolates. e-h European isolates 
Table 5. Thermal tolerance of whole plants of Devaleraea ramentacea in trials of 3 months duration. $\mathrm{L}=$ long days $(16 \mathrm{~h}), \mathrm{S}=$ short days $(8 \mathrm{~h}), \mathrm{D}=$ dark $_{\mathrm{i}}++=$ undamaged,$+=$ damaged but recovered, $-=$ dead (time to death in brackets), nd = no data

\begin{tabular}{|c|c|c|c|c|c|c|}
\hline \multirow[t]{2}{*}{ Isolate } & \multicolumn{6}{|c|}{ Temperature $\left({ }^{\circ} \mathrm{C}\right)$ and Daylength } \\
\hline & $-2 \mathrm{~S}$ & $\mathrm{OL}$ & $O D$ & $18 \mathrm{~L}$ & $20 \mathrm{~L}$ & $23 \mathrm{~L}$ \\
\hline DCAN1 & ++ & ++ & nd & ++ & + & $-(6 \mathrm{wk})$ \\
\hline DCAN2 (m) & ++ & ++ & ++ & ++ & + & $-(2 \mathrm{wk})$ \\
\hline DCAN2 (t) & ++ & ++ & ++ & ++ & + & $-(2 \mathrm{wk})$ \\
\hline DCAN3 & ++ & ++ & ++ & ++ & + & $-(6 \mathrm{wk})$ \\
\hline DJM & ++ & ++ & ++ & + & $-(4 \mathrm{wk})$ & $-(1 \mathrm{wk})$ \\
\hline DNOR1 & $+t$ & ++ & ++ & + & $-(3 \mathrm{wk})$ & $-(2 \mathrm{wk})$ \\
\hline DNOR2 & ++ & ++ & ++ & + & $-(6 \mathrm{wk})$ & $-(2 \mathrm{wk})$ \\
\hline DICE & ++ & ++ & ++ & + & $-(4 \mathrm{wk})$ & $-(2 \mathrm{wk})$ \\
\hline
\end{tabular}

Table 6. Survival of apices of Devaleraea ramentacea from the eastern and western Atlantic after different periods of time at -5 and $-20^{\circ} \mathrm{C}$ ( $\mathrm{n}$ in brackets). Treatments were: $\mathrm{W}=$ immersed in water, $\mathrm{D}=$ in air, $\mathrm{DD}=$ in air after drying at $4^{\circ} \mathrm{C}$ ( $\%$ fresh weight in brackets). ${ }^{*}=$ Apices damaged

\begin{tabular}{|c|c|c|c|c|c|}
\hline \multirow{3}{*}{$\begin{array}{l}\text { Isolates } \\
\text { DCAN1-3 }\end{array}$} & \multirow{2}{*}{\multicolumn{2}{|c|}{$\begin{array}{c}\text { Treatment } \\
(\% \mathrm{FW})\end{array}$}} & & \multicolumn{2}{|c|}{ \% Survival (n) } \\
\hline & & & & $-5^{\circ} \mathrm{C}$ & $-20^{\circ} \mathrm{C}$ \\
\hline & DD & $(70 \%)$ & $4 \mathrm{~h}$ & nd & $25(16)$ \\
\hline & & $(70 \%)$ & $1 \mathrm{~d}$ & nd & $0(8)$ \\
\hline & & $(70-80 \%)$ & $7 \mathrm{~d}$ & $0(8)$ & $12(16)$ \\
\hline & D & & $1 \mathrm{~h}$ & $100(4)$ & nd \\
\hline & & & $4 \mathrm{~h}$ & $100(4)$ & $100(8)$ \\
\hline & & & $1 \mathrm{~d}$ & $50(4)$ & $50(8)$ \\
\hline & & & $7 \mathrm{~d}$ & $75(8)$ & $0(16)$ \\
\hline & $\mathrm{W}$ & & $4 \mathrm{~h}$ & $100(8)$ & $100(8)$ \\
\hline & & & $1 \mathrm{~d}$ & $100(8)$ & $50(8)$ \\
\hline & & & $7 \mathrm{~d}$ & $100(8)$ & $6(16)$ \\
\hline \multirow{10}{*}{ DJM/NOR/ICE } & DD & $(45-55 \%)$ & $4 \mathrm{~h}$ & nd & $14(16)$ \\
\hline & & $(45-55 \%)$ & $1 \mathrm{~d}$ & nd & $14(16)$ \\
\hline & & $(35-70 \%)$ & $7 \mathrm{~d}$ & $0(16)$ & $12(32)$ \\
\hline & D & & $1 \mathrm{~h}$ & $100(4)$ & nd \\
\hline & & & $4 \mathrm{~h}$ & $100(8)$ & $100(8)$ \\
\hline & & & $1 \mathrm{~d}$ & $100(8)$ & $62(16)$ \\
\hline & & & $7 \mathrm{~d}$ & $100(16)$ & $0(16)$ \\
\hline & W & & $4 \mathrm{~h}$ & $100(16)$ & nd \\
\hline & & & $1 \mathrm{~d}$ & $100(16)$ & $74(16)$ \\
\hline & & & $7 \mathrm{~d}$ & $67(16)$ & $50 *(16)$ \\
\hline
\end{tabular}

\section{Phycodrys rubens}

Growth. No significant differences in growth rate were found among either eastern or western Atlantic isolates of Phycodrys rubens but the two groups of isolates did vary significantly from one other. Growth rates of all isolates were comparable at low temperatures but over the optimum range of $10-15^{\circ} \mathrm{C}$, the European plants grew much 
faster (Fig. 5). Blades from European plants were also able to grow for at least 2 weeks at $20^{\circ} \mathrm{C}$, whereas Canadian isolates died within days at this temperature (Fig. 5). European isolates did not grow at $22^{\circ} \mathrm{C}$, but neither did they die within 4 weeks. There were no significant differences in growth with photon fluence rate (all temperatures) or with daylength $\left(0^{\circ} \mathrm{C}\right.$ only).
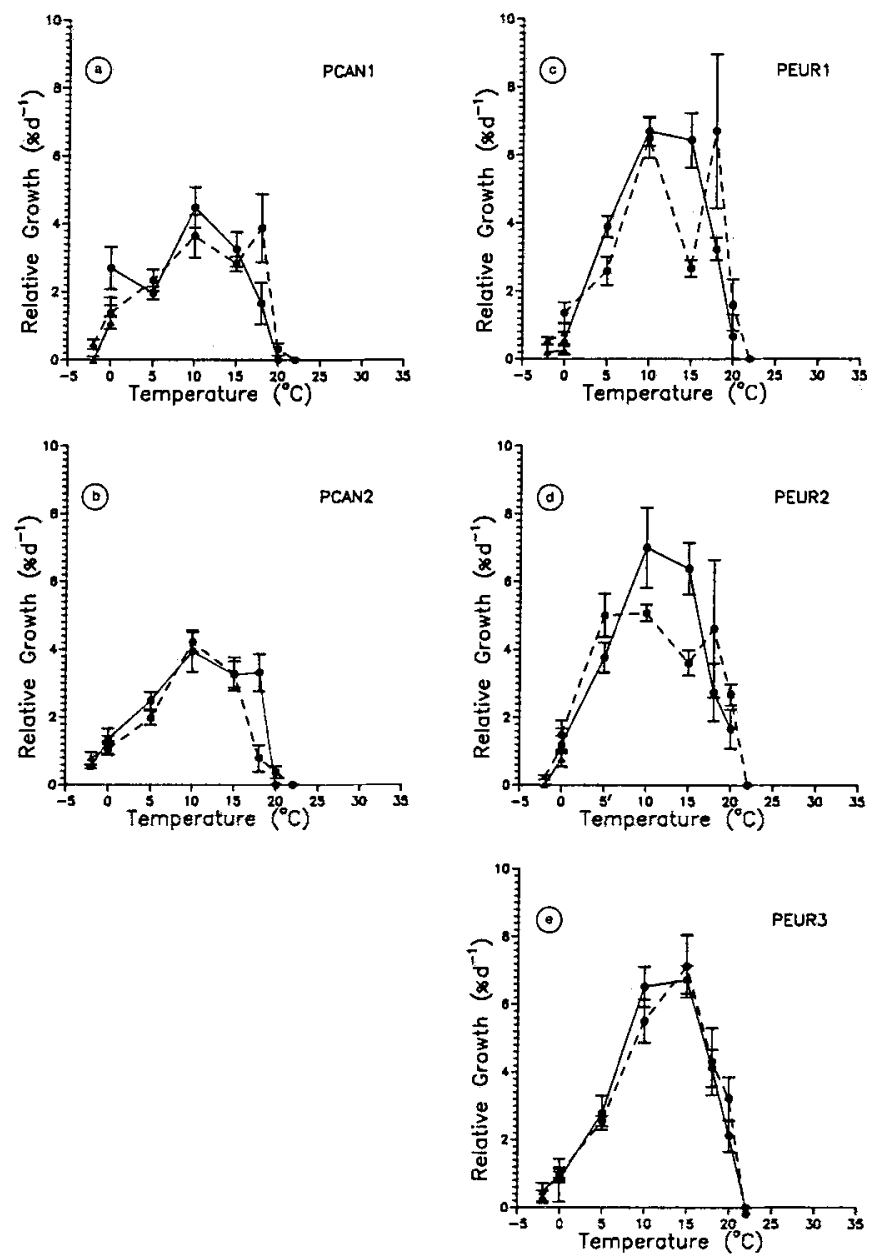

Fig. 5. Relative growth rates (mean \pm standard error) of isolates of Phycodrys rubens at various temperatures at photon fluence rates of $10 \mu \mathrm{mol} \mathrm{m}^{-2} \mathrm{~s}^{-1}$ (dashed line) and $40 \mu \mathrm{mol} \mathrm{m} \mathrm{m}^{-2} \mathrm{~s}^{-1}$ (solid line) in 8-h days (triangles) or 16-h days (circles). Isolate indicated in upper right hand corner of each graph. a-b Canadian isolates. c-e European isolates

High-temperature tolerance. In long-term ( 3 months) exposures to high temperatures (Table 7 ), both Canadian and European isolates died at $20^{\circ} \mathrm{C}$. The two Canadian isolates and one European (PEUR1) sustained damage at $18^{\circ} \mathrm{C}$.

Low-temperature tolerance. All isolates tolerated $-2^{\circ} \mathrm{C}$ in the light and $0^{\circ} \mathrm{C}$ in light or darkness for 3 months (Table 7). When frozen in water to $-5^{\circ} \mathrm{C}$, the 
Table 7. Thermal tolerance of whole plants of Phycodrys rubens in trials of 3 months duration. $\mathrm{L}=$ long days $(16 \mathrm{~h}), \mathrm{S}=$ short days $(8 \mathrm{~h}), \mathrm{D}=$ dark $_{\mathbf{i}}++=$ undamaged,$+=$ damaged but recovered, $-=$ dead, $n d=$ no data

\begin{tabular}{|lccccccc|}
\hline Isolate & \multicolumn{7}{c|}{ Temperature $\left({ }^{\circ} \mathrm{C}\right)$ and Daylength } \\
& $-2 \mathrm{~S}$ & $\mathrm{OL}$ & $\mathrm{OD}$ & $18 \mathrm{~L}$ & $20 \mathrm{~L}$ & $23 \mathrm{~L}$ & $25 \mathrm{~L}$ \\
\hline PCAN1 & ++ & ++ & ++ & + & - & - & - \\
PCAN2 & ++ & ++ & ++ & + & - & - & - \\
PEUR1 & ++ & ++ & nd & + & - & - & - \\
PEUR3 & ++ & ++ & ++ & ++ & - & - & - \\
\hline
\end{tabular}

Table 8. Tolerance of laminae of Phycodrys rubens to freezing in ice at $-5^{\circ} \mathrm{C}$ for up to 2 weeks. $+=$ alive,$-=$ dead,$+-=$ some replicates alive and some dead. $\mathrm{N}=4$ for each combination of isolate and condition

\begin{tabular}{|c|c|c|c|c|c|}
\hline \multirow[t]{2}{*}{ Isolate } & \multicolumn{5}{|c|}{ Duration of Freezing (days) } \\
\hline & 1 & 3 & 5 & 7 & 14 \\
\hline PCAN1 & + & + & + & + & + \\
\hline PCAN2 & + & + & + & + & + \\
\hline PEUR1 & + & + & - & - & - \\
\hline PEUR2 & + & + & + & - & - \\
\hline PEUR3 & + & +- & - & - & - \\
\hline
\end{tabular}

Canadian isolates remained healthy for at least two weeks, while European material died after $3-5$ days (Table 8 ).

\section{DISCUSSION}

In trying to determine the best experimental procedure to reflect potential survival at geographic limits, we tested plants for both 2-wk and 3-mo time periods. In contrast to earlier reports (Yarish et al., 1987), results from three-month trials at high temperatures provided upper limits that were several degrees below those indicated in two-week trials. The longer trials may therefore better represent the effect of a summer season in the field. It is also important to note the evidence that a rapid decline in growth rate over the first 2-3 weeks is characteristic of plants experiencing sub-lethal high temperatures. This loss of growth potential may in fact mark the true upper limit for long-term survival in the field, as plants would lose the ability to replace lost biomass. In species lacking perennating structures or an alternate morphological phase this could result in local extinction. For algae of this sort, it may be best to monitor growth for $2-4$ weeks at high temperatures rather than attempt to measure survival. Loss of growth potential is more easily quantified than plant death, and does not involve the long incubations needed to establish regenerative ability. For those plants having alternate or perennating structures, however, there is no alternative to long-term incubation of the relevant structures.

In the three pan-Arctic algae we have studied, three different patterns of variation in thermal tolerance have been observed.

Among isolates of Chaetomorpha melagonium, there were no differences in lower 
lethal limits or in growth rates and only a minor difference in upper lethal limits. This alga combined a relatively high upper thermal limit with consistently low growth rates at very low temperatures. All isolates were intolerant of desiccation but were able to survive freezing at $-20^{\circ} \mathrm{C}$ for 1 day and tolerated freezing at $-5^{\circ} \mathrm{C}$ for at least 1 week.

Both Devaleraea ramentacea and Phycodrys rubens had upper thermal limits of 18-20 or $20-23^{\circ} \mathrm{C}$, which is characteristic of seaweeds with an Arctic to cold temperate distribution (Lüning, 1985). The upper thermal limits determined for European isolates of D. ramentacea corroborate findings by Rueness \& Tananger (1984). In this species, growth rates at low temperatures were exceptionally high, especially in one Canadian isolate which had the lowest temperature optimum $\left(0^{\circ} \mathrm{C}\right)$ yet recorded in an Arctic macroalga. Also, growth at low temperatures was enhanced when plants were kept at high photon fluence rates and long days, in contrast to southerly species which are often damaged when experiencing high light levels at low temperatures (e.g. Cambridge et al., 1987; Yarish et al., 1984; 1986). D. ramentacea tolerated both desiccation and freezing to $-20^{\circ} \mathrm{C}$ better than did $C$. melagonium. Interestingly, the Canadian isolates of $D$. ramentacea that grew well at low temperatures also had upper lethal limits that were several degrees higher than those of European isolates. In $P$. rubens, the situation was reversed. European plants were the most sensitive to freezing but also were more heat tolerant over the short term. In this species, as in C. melagonium, growth was limited at very low temperatures.

Pan-Arctic algae on opposite sides of the Atlantic Ocean may, therefore, be uniform in their thermal tolerance; they may also exhibit ecotypic variation in terms of growth or survival.

Although thermal ecotypes certainly exist, it is of interest to note that the variations in absolute tolerance that have been found to date within good morphological species do not, in general, exceed $2-3^{\circ} \mathrm{C}$. Also, in some species thermal tolerance does not vary over wide geographic distances (Breeman, 1988), even when the populations have been disjunct and under different thermal regimes for millions of years. Major differences in absolute tolerance have, so far, only been found between eastern and western Atlantic populations of species with a tropical to (warm)-temperate distribution. For instance, in Cladophora coelothrix Kuetz. the lower limit for survival differed by more than $5^{\circ} \mathrm{C}$ between a Caribbean and a European isolate (Cambridge et al., 1987), and the same pattern has been found in several red algae of this distribution-type (Breeman, unpubl.). This must reflect the longer divergence time between eastern and western Atlantic populations in these presumably Tethyan species compared with species of more northerly distribution.

Thermal tolerance, then, appears to be a relatively stable genetic feature. In contrast, sublethal growth rates (Innes, 1988), copper tolerance (Russell \& Morris, 1970), salinity tolerance (Russell \& Bolton, 1975), daylength response (Lüning, 1980), photophysiology (Gerard, 1988) and nutrient physiology (Espinosa \& Chapman, 1983) all may vary widely within narrow latitudinal ranges.

Because of its stable nature, thermal tolerance may be a valuable clue in sorting out evolutionary relationships, patterns of origin and past geographical distributions of groups of isolates and species (Lüning et al., 1987). For instance, the slightly but distinctly different thermal responses of eastern and western isolates of $D$. ramentacea and $P$. rubens indicate that populations have once been effectively isolated even though the 
distribution is now continuous through the Arctic. The similarity of the Icelandic isolate of D. ramentacea to other European isolates indicates that recolonization of the Icelandic coast after the glaciation has occurred from the European side of the ocean.

However, the reasons why species should have developed somewhat different patterns of variation in their thermal responses are not immediately clear. For instance, the broadening of the thermal range found in Canadian isolates of $D$. ramentacea, which makes them better adapted to the strong seasonality on that side of the ocean, has not occurred in $P$. rubens where, instead, there was a downward shift in the thermal range. Before we can further speculate on possible evolutionary origins of isolates and species, we need to know more about the temperature requirements for reproduction and about the morphology and thermal tolerances of putative con-specific populations occurring in the North Pacific.

Acknowledgements. We wish to thank those colleagues who kindly provided either field or culture material for our culture collection: C. J. Bird, J. R. Hansen, W. Kooistra, Dr. J. McLachlan, Dr. A. Peters, and Dr. J. Rueness. Thanks also to Prof. C. van den Hoek for his support, Ms T. Linders for technical assistance, and the Netherlands Organisation for the Advancement of Pure Research (ZWO) for the financial support provided for the senior author.

\section{LITERATURE CITED}

Berggren, W. A. \& Hollister, C. D., 1977. Plate tectonics and palaeocirculation - a commotion in the ocean. - Tectonophysics $38,11-48$.

Breeman, A. M., 1988. Relative importance of temperature and other factors in determining geographic boundaries of seaweeds: experimental and phenological evidence. - Helgoländer Meeresunters. 42, 199-241.

Breeman, A. M., 1990. Expected effects of changing seawater, temperatures on the geographic distribution of seaweed species. In: Expected effects of climatic change on marine coastal ecosystems. Ed. by J. J. Beukema, W. J. Wolff \& J. J. W. M. Brouns. Kluwer, Dordrecht, 69-76.

Briggs, J. C., 1987. Biogeography and plate tectonics. Elsevier, Amsterdam, 204 pp.

Cambridge, M. L., Breeman, A. M., Kraak, S. \& Hoek, C. van den, 1987. Temperature responses of tropical to warm temperate Cladophora species in relation to their distribution in the North Atlantic Ocean. - Helgoländer Meeresunters. 41, 329-354.

CLIMAP Project Members, 1981. Seasonal reconstructions of the earth's surface at the last glacial maximum. - The Geological Society of America Map and Chart Series, MC-36.

Espinosa, J. \& Chapman, A. R. O., 1983. Ecotypic differentation of Laminaria longicruris in relation to seawater nitrate concentration. - Mar. Biol. 74, 213-218.

Frakes, L. A., 1979. Climates throughout geologic time. Elsevier, Amsterdam, 310 pp.

Gerard, V. A., 1988. Ecotypic differentiation in light-related traits of the kelp Laminaria saccharina. Mar. Biol. 97, 25-36.

Hoek, C. van den, 1984. World-wide latitudinal and longitudinal seaweed distribution patterns and their possible causes, as illustrated by the distribution of Rhodophytan genera. - Helgoländer. Meeresunters. 38, 227-257.

Hoek, C. van den, \& Breeman, A. M., 1990. Seaweed biogeography of the North Atlantic Ocean: where are we now? In: Evolutionary biogeography of the marine algae of the North Atlantic. Ed. by G. R. South \& D. Garbary. Elsevier, Amsterdam (in press)

Innes, D. J., 1988. Genetic differentiation in the intertidal zone in populations of the alga Enteromorpha linza (Ulvales: Chlorophyta). - Mar. Biol. 97, 9-16.

Kain, J. M., 1987. Seasonal growth and photoinhibition in Plocamium cartilagineum (Rhodophyta) off the Isle of Man. - Phycologia 26, 88-99.

Lamb, H. H., 1977. Climate: Present, past and future. Methuen, London, 2, 1-835.

Lüning, K., 1980. Control of algal life history by daylength and temperature. In: The shore 
environment. Ed. by J. H. Price, D. E. G. Irvine \& W. F. Farnham. Acad. Press, London, 2 , 915-945.

Lüning, K., 1985. Meeresbotanik. Thieme, Stuttgart, 375 pp.

Lüning, K., Guiry, M. D. \& Masuda, M., 1987. Upper temperature tolerance of North Atlantic and North Pacific geographical isolates of Chondrus species (Rhodophyta). - Helgoländer Meeresunters. 41, 297-306.

McKenna, M. C., 1983. Cenozoic paleogeography of North Atlantic land bridges. In: Structure and development of the Greenland Scotland Ridge, new methods and concepts. Ed. by M. H. P. Bott, S. Saxov, M. Talwani, \& J. Thiede. Plenum Press, New York, 351-399.

McLachlan, J., 1973. Growth media - marine. In: Handbook of phycological methods: culture methods and growth measurements. Ed. by J. Stein. Cambridge Univ. Press, Cambridge, 25-51.

Rueness, J. \& Tananger, T., 1984. Growth in culture of four red algae from Norway with potential for mariculture. - Hydrobiologia 116-117, 303-307.

Russell, G. \& Bolton, J. J., 1975. Euryhaline ecotypes of Ectocarpus siliculosus (Dillw.) Lyngb. Estuar. coast. mar. Sci. 3, 91-94.

Russell, G. \& Morris, O. P., 1970. Copper tolerance in the marine fouling alga, Ectocarpus siliculosus. - Nature, Lond. 228, 288-289.

Smith, A. G., Hurley, A. M. \& Briden, J. C., 1981. Phanerozoic paleocontinental world maps. University Press, Cambridge, $102 \mathrm{pp}$.

Thiede, J., 1979. History of the North Atlantic Ocean: evolution of an asymmetric zonal paleoenvironment in a latitudinal ocean basin. In: Deep drilling results in the Atlantic Ocean: continental margins and paleoenvironment. Ed. by M. Talwani, W. Hay \& W. B. F. Ryan. American Geophysical Union, Washington, 275-296.

Thiede, J. \& Endholm, O., 1983. Speculations about the paleodepth of the Greenland-Scotland Ridge during the late Mesozoic and Cenozoic. In: Structure and development of the GreenlandScotland Ridge. Ed. by M. H. P. Bott, S. Saxov, M. Talwani \& J. Thiede. Plenum Press, New York, 351-399.

Thunell, R. \& Belyea, P., 1982. Neogene planktonic foraminiferal biogeography of the Atlantic Ocean. - Micropaleontology 28, 381-398.

Yarish, C., Breeman, A. M. \& Hoek, C. van den, 1984. Temperature, light and photoperiod responses in some Northeast American and West European endemic rhodophytes in relation to their geographic distribution. - Helgoländer Meeresunters. 38, 273-304.

Yarish, C., Breeman, A. M. \& Hoek, C. van den, 1986. Survival strategies and temperature responses of seaweeds belonging to different distribution groups. - Botanica mar. 29, 215-230.

Yarish, C., Kirkman, H. \& Lüning, K., 1987. Lethal exposure times and preconditioning to upper temperature limits of some temperate North Atlantic red algae. - Helgoländer Meeresunters. 41. 323-327. 